\title{
Comprehensive dosimetry for seven exposure sources at the earliest US uranium processing facility
}

\author{
Elizabeth D. Ellis ${ }^{1,}$, Richard W. Leggett ${ }^{2}$, Ashley P. Golden ${ }^{1}$, and John D. Boice, $\mathrm{Jr}^{3}$ \\ ${ }^{1}$ Oak Ridge Institute for Science and Education, 100 ORAU Way, Oak Ridge, TN 37831, USA \\ ${ }^{2}$ Oak Ridge National Laboratory, Oak Ridge, TN 37830, USA \\ ${ }^{3}$ National Council on Radiation Protection and Measurements, 7910 Woodmont Ave, Bethesda, MD \\ 20814, USA; Vanderbilt University Medical School, 2525 West End Ave, Nashville, TN 37203, USA
}

\section{Abstract}

Mallinckrodt Chemical Works (MCW) was the earliest uranium processing facility in the United States, beginning in 1942 . The 2,514 workers included in the epidemiologic study were exposed to external gamma radiation, medical x-rays, internal radiation from intakes of pitchblende ore and its extracted radionuclides (mainly uranium isotopes and radium226), and ambient levels of radon and its progeny [1].

Multiple sources of exposure data were available to a degree unique for an epidemiologic study [2]. Personal film badges captured external exposures in 12,686 records. Additional external exposure included over 31,297 occupational medical x-rays and 210 exposure records from employment outside of MCW. Organ dose estimates were adjusted for photon energy and job-specific orientation of workers to the radiation source during processing. Intakes of uranium and radium were based on 39,451 uranium urine bioassays and 2,341 breath radon measurements using International Commission on Radiological Protection (ICRP) biokinetic models to estimate organ-specific radiation absorbed dose [3]. Estimates of exposure to airborne radon and its progeny were available from 6,846 ambient radon measurements in work areas where radium-containing material was handled or stored, together with estimated exposure times in these areas based on job titles. Dose estimates for radon progeny were based on models and methods recently recommended by ICRP [4]. Contributions of uranium dust and silica exposures to risk were estimated from 6,300gol worker-specific estimates of daily exposure to uranium dust [2]. These data were used to calculate job-specific daily time-weighted average dust exposures. Because intake of uranium is best described by bioassay data, the dust exposures were used to explore potential associations with heavy metal toxicity and silica, independent of the radioactive content.

This comprehensive dosimetric approach follows methods outlined by the National Council on Radiation Protection Scientific Report 178 for the Million Worker Study [5]. Annual doses were calculated for 6 organs: lung, brain, heart, kidney, colon and red bone marrow. Mean and median dose estimates for external, internal, and total radiation exposure for each organ of interest are listed in Table 1.

\footnotetext{
* Corresponding author: betsy.ellis@orau.org
} 
Table 1. Summary of contributions of each exposure source to organ-specific doses

\begin{tabular}{|c|c|c|c|c|c|c|c|}
\hline \multirow[t]{2}{*}{ Organ } & \multicolumn{2}{|c|}{$\begin{array}{c}\text { External-Film } \\
\text { Badge/TLD } \\
\mathrm{N}=2,514\end{array}$} & \multicolumn{2}{|c|}{$\begin{array}{c}\text { External-Medical } \\
\text { x-ray } \\
\mathrm{N}=2,514 \\
\end{array}$} & $\begin{array}{c}\text { Internal } \\
\mathrm{U} \text { and } \mathrm{Ra} \\
\mathrm{N}=1,886 \\
\end{array}$ & \multicolumn{2}{|c|}{$\begin{array}{c}\text { Total External + } \\
\text { Internal } \\
\mathrm{N}=2,514 \\
\end{array}$} \\
\hline & & & $\begin{array}{r}\text { Mear } \\
\text { Media }\end{array}$ & $\begin{array}{l}\text { dose in } \mathrm{m} \\
\text { dose in } \mathrm{m}\end{array}$ & $\begin{array}{l}{[\mathrm{Std}]} \\
{[\mathrm{Max}]}\end{array}$ & & \\
\hline Lung & $\begin{array}{l}36.0 \\
11.2\end{array}$ & $\begin{array}{r}{[68.9]} \\
{[724.2]}\end{array}$ & $\begin{array}{r}10.7 \\
7.2\end{array}$ & $\begin{array}{r}{[8.7]} \\
{[53.6]}\end{array}$ & $\begin{array}{lr}27.1 & {[39.2]} \\
11.2 & {[416.3]}\end{array}$ & $\begin{array}{l}69.9 \\
33.1\end{array}$ & $\begin{array}{l}{[103.0]} \\
{[885.2]}\end{array}$ \\
\hline Brain & $\begin{array}{l}33.0 \\
10.7\end{array}$ & $\begin{array}{r}{[62.5]} \\
{[738.4]}\end{array}$ & $\begin{array}{l}4.2 \\
3.0\end{array}$ & $\begin{array}{r}{[3.6]} \\
{[20.0]}\end{array}$ & $\begin{array}{ll}0.079 & {[0.1]} \\
0.040 & {[1.4]}\end{array}$ & $\begin{array}{l}37.2 \\
15.2\end{array}$ & $\begin{array}{r}{[63.9]} \\
{[749.6]}\end{array}$ \\
\hline Heart & $\begin{array}{l}35.6 \\
11.0\end{array}$ & $\begin{array}{r}{[68.4]} \\
{[710.8]}\end{array}$ & $\begin{array}{r}11.8 \\
8.0\end{array}$ & $\begin{array}{r}{[9.7]} \\
{[59.3]}\end{array}$ & $\begin{array}{ll}0.089 & {[0.1]} \\
0.044 & {[1.4]}\end{array}$ & $\begin{array}{l}47.5 \\
23.3\end{array}$ & $\begin{array}{r}{[73.0]} \\
{[737.6]}\end{array}$ \\
\hline Kidney & $\begin{array}{r}27.9 \\
8.9\end{array}$ & $\begin{array}{r}{[53.1]} \\
{[603.5]}\end{array}$ & $\begin{array}{r}10.7 \\
7.2\end{array}$ & $\begin{array}{r}{[8.7]} \\
{[53.6]}\end{array}$ & $\begin{array}{lr}0.73 & {[0.9]} \\
0.41 & {[11.6]}\end{array}$ & $\begin{array}{l}39.2 \\
20.2\end{array}$ & $\begin{array}{r}{[57.9]} \\
{[637.5]}\end{array}$ \\
\hline Colon & $\begin{array}{l}35.6 \\
11.0\end{array}$ & $\begin{array}{r}{[68.4]} \\
{[711.5]}\end{array}$ & $\begin{array}{l}2.3 \\
1.8\end{array}$ & $\begin{array}{r}{[1.9]} \\
{[11.9]}\end{array}$ & $\begin{array}{l}0.13 \\
0.05\end{array}$ & $\begin{array}{l}38.0 \\
13.4\end{array}$ & $\begin{array}{r}{[69.4]} \\
{[713.5]}\end{array}$ \\
\hline $\begin{array}{l}\text { Bone } \\
\text { marrow }\end{array}$ & $\begin{array}{c}32.9 \\
10.3\end{array}$ & $\begin{array}{r}{[62.9]} \\
{[675.5]}\end{array}$ & $\begin{array}{l}2.2 \\
1.8\end{array}$ & $\begin{array}{r}{[1.9]} \\
{[11.1]}\end{array}$ & $\begin{array}{lr}0.57 & {[1.1]} \\
0.18 & {[10.3]}\end{array}$ & $\begin{array}{l}35.6 \\
12.9\end{array}$ & $\begin{array}{r}{[64.3]} \\
{[682.7]}\end{array}$ \\
\hline
\end{tabular}

The largest organ doses were to the lung (mean $69.9 \mathrm{mGy}$; max $885 \mathrm{mGy}$ ) and heart (mean $47.5 \mathrm{mGy}$; max $737.6 \mathrm{mGy}$ ). External gamma dose was the largest contributor to dose for all organs, but doses from medical $\mathrm{x}$-rays were also important. Average annual dust exposure was $15.1 \mathrm{mg} / \mathrm{m}^{3}$ (max $\left.400 \mathrm{mg} / \mathrm{m}^{3}\right)$.

The extensive collection of radiation exposure data available for the MCW workers provides the broadest application to date of the methodology endorsed by the NCRP [5] for construction of organ doses for use in epidemiologic studies. Such comprehensive dosimetry is required to produce the best radiation risk estimates for addressing current radiation issues on the effectiveness of low dose-rate exposures. These estimates are relevant to: projecting risks from environmental contamination from nuclear waste, terrorist events, and radiations used in medical diagnosis or treatment; compensation issues related to prior exposures; improved protection standards for workers and the public; evaluation of the safety and radiation risks for astronauts leaving Earth's orbit; and appropriateness of the linear non-threshold model as a principle for radiation protection guidance.

\section{References}

1. J.D Boice Jr., E.D. Ellis, A.P. Golden, D.J. Girardi, S.S. Cohen, H. Chen, M.T. Mumma, R.E. Shore, R.W. Leggett. Health Phys., 114(4): 381-385 (2018).

2. E.D. Ellis, J.D. Boice Jr., A.P. Golden, D.J. Girardi, S.S. Cohen, M.T. Mumma, R.E. Shore, R.W. Leggett, G.D. Kerr. Health Phys., 114(4): 386-297 (2018).

3. International Commission on Radiological Protection. Dose coefficients for intakes of radionuclides by workers: Part 4. New York: Elsevier; ICRP Publication 68, Ann ICRP 24(4) (1994).

4. International Commission on Radiological Protection. Occupational intakes of radionuclides: Part 3. London: Sage; ICRP Publication 137, Ann ICRP 46(3-4) (2017).

5. National Council on Radiation Protection and Measurements. Deriving organ doses and their uncertainty for epidemiologic studies (with a focus on the One Million U.S. Workers and Veterans Study of Low-dose Radiation Health Effects). Bethesda, MD; NCRP Report No. 178 (2018). 